\title{
Silage Fermentation: A Potential Microbial Approach for the Forage Utilization of Cyperus esculentus L. By-Product
}

\author{
Jiahao Sun ${ }^{1,2,+}$, Tianwei Wang ${ }^{1,+}$, Fuqing Huang ${ }^{1}$, Yayong Liu ${ }^{1}$, Weixiong Shi ${ }^{1,2}$, Cui Ma ${ }^{1}$ and Jin Zhong ${ }^{1,2, *}$ \\ 1 State Key Laboratory of Microbial Resources, Institute of Microbiology, Chinese Academy of Sciences, \\ Beijing 100101, China; sunjh@im.ac.cn (J.S.); wangtw@im.ac.cn (T.W.); huangfq@im.ac.cn (F.H.); \\ liuyy@im.ac.cn (Y.L.); shiweixiong@cnilas.org (W.S.); 82101211103@caas.cn (C.M.) \\ 2 School of Life Science, University of Chinese Academy of Sciences, Beijing 100039, China \\ * Correspondence: zhongj@im.ac.cn; Tel.: +86-010-6480-7401 \\ + Authors contributed equally to this work.
}

Citation: Sun, J.; Wang, T.; Huang, F.; Liu, Y.; Shi, W.; Ma, C.; Zhong, J. Silage Fermentation: A Potential Microbial Approach for the Forage Utilization of Cyperus esculentus L. By-Product. Fermentation 2021, 7, 273. https://doi.org/10.3390/

fermentation7040273

Academic Editor: Qing Zhang

Received: 9 October 2021

Accepted: 21 November 2021

Published: 23 November 2021

Publisher's Note: MDPI stays neutral with regard to jurisdictional claims in published maps and institutional affiliations.

Copyright: () 2021 by the authors. Licensee MDPI, Basel, Switzerland. This article is an open access article distributed under the terms and conditions of the Creative Commons Attribution (CC BY) license (https:// creativecommons.org/licenses/by/ $4.0 /)$.

\begin{abstract}
Cyperus esculentus L. leaves (CLL) are agricultural by-products produced from Cyperus esculentus L. harvesting, and can be used as livestock feed despite their low economic value for human consumption. This study aims to develop a favorable approach to processing Cyperus esculentus L. by-product as coarse fodder. The chopped CLL was pretreated by (1) mixing with canola straw at a 4:1 ratio, or (2) wilting it for $8 \mathrm{~h}$, then it ensiling with or without compounded lactic acid bacteria (LAB) additives for 60 days. Our results demonstrated that compounded LAB additives: improved CLL silage fermentation quality by increasing acetic acid and lactic acid contents and decreasing ethanol and ammonia-N contents; preserved nutrients by raising the level of crude protein and water soluble carbohydrates; modified the bacterial community by increasing the relative abundance of Lactobacillus while decreasing the relative abundance of undesirable Enterococcus; and also might improve animal health by increasing the relative concentrations of antioxidant substances (such as 7-galloylcatechin) and antibacterial compounds (such as ferulic acid). This study provides strong evidence that Cyperus esculentus L. by-product can be a potential livestock feed after being ensiled with compounded $\mathrm{LAB}$ additives.
\end{abstract}

Keywords: Cyperus esculentus L.; silage fermentation; microbial community; forage resource; metabolomics

\section{Introduction}

The perennial herb Cyperus esculentus L. comes from the family Cyperaceae, and is also known as tiger nuts [1-3]. After it was first introduced to China in 1952, it was widely planted due to its resistance to cold temperatures, drought, waterlogging, barrenness, salt, and alkaline conditions; the productivity of Cyperus esculentus L. tubers can reach 15-18 t/hm ${ }^{2}$ [4]. Cyperus esculentus L. is comprised of above-ground leaves, underground tubers and roots [5]. The nutritional value of these plant parts means that Cyperus esculentus L. can serve as a beneficial crop for both humans and animals [6]. Tubers with rich flavor and fats have historically been melted into "Horchata de Chufa," a kind of drink with a nutty taste, and squeezed oil, leaving by-products such as leaves, which are typically burned or discarded [1,7].

However, Cyperus esculentus L. leaves (CLL) is a source of polysaccharides, fiber, and antioxidant compounds (such as vitamin $\mathrm{E}$ and polyphenols). CLL is comprised of $9.8 \%$ crude protein (CP) and 19.3\% crude fiber, meaning its leaves can also be used as functional silage materials [4]. The CP content of CLL is similar to that of oats (Avena sativa), which are known for their high protein content and digestible fraction $[8,9]$. This suggests that CLL could be used as livestock feed, especially in the absence of high-quality forage. If mixed with forage and fed to cows, it can increase milk yield while decreasing cost [4]. Jing et al. have reported the neuroprotective capacity of Cyperus esculentus L. orientin obtained from CLL [5]. The antioxidant capability of silage can increase the accumulation of desirable 
fatty acids in the milk and meat of livestock, and improve the antioxidant capabilities of meat, as well as aid in fighting off rumen bloat [10]. Despite the potential benefits of CLL, it is still underutilized and there is little information about how it can be used as a coarse fodder.

Ensiling is typically the most effective and economical method to preserve fresh forage grass and it can improve palatability and prolong the maximum storage duration via anaerobic fermentation [11,12]. For silage fermentation, the low dry matter (DM) content $(19.9 \%)$, the low water-soluble carbohydrates (WSC) content $(2.52 \% \mathrm{DM})$, and the low level of epiphytic lactic acid bacteria (LAB, $<10^{5}$ colony-forming units (CFU) $/ g$ fresh matter (FM)) of fresh CLL make it difficult to ensile [12]. The DM content can be adjusted by adding absorbents (such as crops straw) and wilting. The common additives used to obtain high-quality silage are molasses and LAB. Molasses can be used as a soluble carbohydrate for LAB metabolism, and is subsequently converted into lactic acid to decrease silage $\mathrm{pH}$ value during the ensiling process $[13,14]$. LAB is divided into homofermentative and heterofermentative strains. Homofermentative LAB strains, such as Lactobacillus plantarum, quickly produce lactic acid, which helps to preserve nutrition by lowering the silage $\mathrm{pH}$ [15]; heterofermentative LAB strains, such as Lactobacillus buchneri, could improve aerobic stability by suppressing the growth of yeast and mold through producing acetic acid. Thus, compounded LAB additives (mainly consisting of L.plantarum CGMCC No.13318, L. buchneri CGMCC No.16534 and molasses) were applied to ensile the agricultural by-product CLL under proper DM content (36-37\%).

This study aims to provide a suitable approach to forage utilization of Cyperus esculentus L. by-product. The effects of compounded LAB additives on CLL silage, pretreated with canola straw or wilted, were evaluated. In particular, the bacteria community and metabolomics were studied, which could provide vital information for further regulation of fermentation and the exploitation of bioactive ingredients.

\section{Materials and Methods}

\subsection{CLL Harvest and Silage Making}

The CLL was harvested from an experimental field of the Yellow River Delta Modern Agricultural Technology Innovation Center $\left(37^{\circ} 67^{\prime} \mathrm{N} ; 118^{\circ} 90^{\prime}\right.$ E) on 19 September 2020. Before ensiling, the harvested CLL were divided into two groups: the Sample 1 (S1) group was mixed with canola straw at a 4:1 ratio, while the Sample 2 (S2) group wilted for $8 \mathrm{~h}$. Following these pretreatments, the DM contents of both groups adjusted to $36-37 \%$.

The CLL were chopped into theoretically $2 \mathrm{~cm}$-long pieces with a crop chopper. Then, they were randomly ensiled with the compound LAB additives, which were comprised of L. plantarum CGMCC No.13318, L. buchneri CGMCC No.16534, and molasses. The inoculants were added at a rate of $10^{6} \mathrm{CFU} / \mathrm{g}$ FM, and the molasses were added at a level of $0.5 \%(w / w)$ FM in treatments (LM in the S1 group and WLM in the S2 group). An equal amount of distilled water was sprayed for the controls without additives (CK in the S1 group and WCK in the S2 group). They were then homogenously mixed with additives or distilled water, after which $300 \mathrm{~g}$ of fresh forage was packed into vacuumsealing polyethylene plastic bags. A total of 24 silos ( 2 groups $\times 2$ treatments $\times 6$ replicates) were maintained at room temperature $\left(21-30{ }^{\circ} \mathrm{C}\right)$. Samples were obtained after 60 days of ensiling.

\subsection{Analysis of Culture-Based Microbial}

To calculate the microbial counts, samples of $10 \mathrm{~g}$ CLL silage were mixed with $90 \mathrm{~mL}$ of a sterile saline solution, after which they were diluted from $10^{-1}$ to $10^{-7}$. One hundred $\mu \mathrm{L}$ were spread on the various agar plates. The amount of LAB was calculated on de Man, Rogosa, Sharpe agar (MRS), which was enumerated at $37^{\circ} \mathrm{C}$ for $48 \mathrm{~h}$ under anaerobic conditions. The yeast and molds were counted on a potato dextrose agar (PDA) and were incubated at $30^{\circ} \mathrm{C}$ for $24 \mathrm{~h}$ under aerobic conditions. Aerobes were calculated on Nutrient Agar (NA) at $37^{\circ} \mathrm{C}$ for $24 \mathrm{~h}$. All culture media were purchased from Beijing Solarbio Science 
\& Technology Co., Ltd. Yeast and molds were distinguished from bacteria according to the appearance and cell morphology of the colony.

\subsection{Fermentation Quality Analysis}

Samples of $10 \mathrm{~g}$ CLL silage were blended with $90 \mathrm{~mL}$ sterilized water, after which they were incubated overnight at $4{ }^{\circ} \mathrm{C}$. They were then filtered through a $0.22 \mu \mathrm{m}$ filter [13]. The resulting extract was used to measure $\mathrm{pH}$ value ( $\mathrm{pH} 213$; HANNA; Italy), the contents of ammonia-N, and organic acid. Levels of ammonia-N were analyzed using the ninhydrin colorimetric and phenol-hypochlorite procedures outlined by Broderick and Kang [16]. The contents of organic acid were assessed by High-Performance Liquid Chromatography (HPLC, 1200, Agilent, California, America) equipped with a $210 \mathrm{~nm}$ UV detector and an ICSep COREGEL-87H column (temperature of column: $55^{\circ} \mathrm{C}$ ). The mobile phase was $0.004 \mathrm{~mol} / \mathrm{L} \mathrm{H}_{2} \mathrm{SO}_{4}$ with a flow rate of $0.6 \mathrm{~mL} / \mathrm{min}$ and an injection volume of $10 \mu \mathrm{L}$. The buffering capacity (BC) was measured according to the methods used by Playne and McDonald [17].

\subsection{Chemical Composition Analysis}

Approximately $150 \mathrm{~g}$ samples (pre-ensiled material and silage sample) were collected. They were then placed in an oven at $65^{\circ} \mathrm{C}$ for $48 \mathrm{~h}$, and the temperature was increased to $105{ }^{\circ} \mathrm{C}$ until they reached a constant weight. The DM content was then calculated as a former record [18]. The dried sample was ground to a particle diameter of $1.0 \mathrm{~mm}$ to analyze the chemical composition. The WSC was determined according to the methods used by Murphy [19] and the CP was examined according to the procedures established by the AOAC [20]. The content of the neutral detergent fiber (NDF), the acid detergent fiber (ADF), and the acid detergent lignin (ADL) were all measured according to the procedures used by VanSoest et al. [21].

\subsection{Bacterial Diversity Sequenced by High-Throughput Sequencing}

Samples of $10 \mathrm{~g}$ CLL silage were randomly selected and vigorously blended with $40 \mathrm{~mL}$ sterilized water at $4{ }^{\circ} \mathrm{C}$ and shaken at $120 \mathrm{rpm}$ for $30 \mathrm{~min}$. The resulting mix was then filtered through a filter $(0.22 \mathrm{~mm}$, Cat. B-CYD400G1), after which it was obtained by centrifugation at $4{ }^{\circ} \mathrm{C}$ at $5000 \mathrm{rpm}$ for $2 \mathrm{~min}$, which removed the impurities and transported the supernatant to obtain microbial pellets. It was then centrifuged at $4{ }^{\circ} \mathrm{C}$ and $12,000 \mathrm{rpm}$ for $10 \mathrm{~min}$. The total DNA was extracted from the samples using a MolPure Soil DNA Kit (Yeasen, Beijing, China), according to the manufacturer's instructions.

Universal primers 338F (ACTCCTACGGGAGGCAGCA) and 806R (GGACTACHVGG GTWTCTAAT) were used to amplify the V3-V4 variable regions of the bacterial 16S rDNA. The PCR reactions were conducted according to the methods used by Su et al. [14]. To minimize PCR deviation, a triple PCR reaction was performed for each sample. Three PCR products were mixed and sequenced using paired-end reads $(2 \times 300 \mathrm{bp})$ with an Illumina MiSeq platform (Shanghai Majorbio Bio-pharm Technology Co. Ltd.) according to standard protocols. The sequenced reads were processed according to the methods used by Ni et al. [22]. The raw tags were quality-filtered and merged using Trimmomatic (Version 3.29) and FLASH (Version 1.2.11). ACE, Simpson, Chao, Shannon, and Good's coverage were all calculated to assess the alpha diversity.

\subsection{Metabolomics Analysis Using LC-MS}

A non-targeted metabolome method was used to evaluate the metabolomics of CLL ensiling with the LC-MS ABSciex Triple TOF 5600TM (ABSCIEX, USA) in Majorbio Biopharm Technology (Shanghai, China) according to the published procedures of a previous study [23]. A partial extract $(75 \mu \mathrm{L})$ from each sample was used for the quality control (QC) samples. The raw data were imported to ProgenesisQI (WatersCorporation, Milford, CT, USA) to normalize the retention times, MZ, observations and peak intensities. According to the characteristic peaks and the MS mass spectra information, the metabolites were matched 
with the metabolic databases such as: http:/ / www.hmdb.ca/ (accessed on 23 March 2021) https:/ / metlin.scripps.edu/ (accessed on 13 April 2021) and self-built databases on the on the Majorbio I-Sanger platform (www.i-sanger.com, accessed on 15 April 2021). The MS mass error was set to less than $10 \mathrm{ppm}$. Relative quantifications of metabolites were carried out as a ratio of their peak areas to the peal area of internal standard substance $(0.02 \mathrm{mg} / \mathrm{mL}$ 2-Chloro-L-Phenylalanine, CAS. 103616-89-3, Adamas-beta). The data were then filtered the missing value, missed value recoding, normalized and logarithmic transformed. Principal component analysis (PCA) and orthogonal partial least-squares-discriminant analysis (OPLS-DA) were carried out to show the metabolism changes among the S1 and S2 groups after mean centering and unit variance scaling. The differential metabolites were defined at the fold change $\geq 1$ or $\leq 0.5$ as well as variable importance in the projection (VIP) of the OPLS-DA model greater than 1.

\subsection{Calculation of Relative Feed Value and Fermentation Coefficient}

Relative feed value (RFV) is a forage evaluation index typically used for assessing intake and energy value and was published by the American Forage and Grassland Council [24]. RFV is calculated by ADF and NDF according to the following formula [24]:

$$
\begin{gathered}
D D M(\% D M)=88.90-0.779 \times A D F(\% D M) \\
D M I(\% B o d y \text { weight })=120 / N D F(\% D M) \\
R F V=(D D M \times D M I) / 1.29
\end{gathered}
$$

DDM: digestible dry matter; DMI: dry matter intake.

To evaluate the ensilability of CLL, a fermentation coefficient $(F C)$ was calculated from $D M \%$ content, WSC content, and BC of CLL according to the following formula [25]:

$$
F C=D M \%+8 \times W S C(\% D M) / B C
$$

\subsection{Statistical Analysis}

Unless otherwise stated, the statistical analyses were conducted using the SAS (version 9.0, 2002; SAS Institute, Cary, NC, USA). The independent sample t-tests of variance were applied to compare the data in S1 and S2 groups, respectively. The significance was declared if $p<0.05$. The data presented are the means \pm standard deviation (SD). Microbial counts were assessed via log 10 and analyzed based on their FM. Correlations between differentially presented metabolites and main bacteria species in the S1 and S2 groups were plotted as Spearman correlations, respectively. $p$ values $<0.05$ were considered statistically significant. ${ }^{*}, p<0.05 ;{ }^{* *}, p<0.01 ;{ }^{* *}, p<0.001$.

\section{Results}

\subsection{Characteristics of Fresh CLL}

Table 1 displays the chemical composition and the number of microorganisms in the raw materials prior to ensiling. In harvested CLL, the DM content was approximately 20\%; the $\mathrm{CP}$ content was $11.56 \% \mathrm{DM}$; the NDF, ADF, and ADL concentrations were $56.08 \% \mathrm{DM}$, $28.92 \%$ DM and $9.54 \%$ DM, respectively; and the WSC content was approximately $2.52 \%$ DM. After it was mixed with canola straw at a 4:1 ratio in the S1 group, the DM content was $37.20 \%$; the CP content was 5.17\% DM; the NDF, ADF, and ADL concentrations were $61.40 \%$ DM, 40.55\% DM, and 4.54\% DM, respectively; and the WSC contents was $6.46 \%$ $\mathrm{DM}$. After wilting for $8 \mathrm{~h}$ in the $\mathrm{S} 2$ group, the DM content was $36.40 \%$; the CP content was $11.96 \%$ DM and the NDF, ADF, and ADL concentrations were 55.10\% DM, 29.40\% DM, and $8.40 \%$ DM, respectively; and the WSC content was 3.20\% DM. Otherwise, the amount of epiphytic LAB, yeast, and aerobes in CLL was close to that of canola straws (which were obtained via plate culturing). The amount of LAB was lower than $10^{5} \mathrm{CFU} / \mathrm{g}$ FM, while the number of yeast and aerobes was approximately $10^{6} \mathrm{CFU} / \mathrm{g}$ FM. 
Table 1. Chemical composition and cultivable microbial population of raw materials before ensiling.

\begin{tabular}{ccccc}
\hline Item & CLL & Canola Straw & S1 & S2 \\
\hline DM\% & 19.90 & Chemical composition & 37.20 & 36.40 \\
CP (\%DM) & 11.56 & 90.78 & 5.17 & 11.96 \\
NDF (\%DM) & 56.08 & 5.21 & 61.40 & 55.10 \\
ADF (\%DM) & 28.92 & 62.40 & 40.55 & 29.40 \\
ADL (\%DM) & 9.54 & 50.51 & 4.54 & 8.40 \\
WSC (\%DM) & 2.52 & 8.53 & 6.46 & 3.20 \\
\hline
\end{tabular}

$\begin{array}{ccccc} & \text { Cultivable microbial population }\left(\log _{10} \mathrm{CFU} / \mathrm{g} \text { FM }\right) & \text { / } \\ \text { Yeast } & 6.71 & 5.16 & / & \text { / } \\ \text { Aerobes } & 6.92 & 6.14 & / & \text { / } \\ \text { LAB } & 4.00 & 4.70 & / & \text { / }\end{array}$

DM, dry matter; FM, fresh matter; $\mathrm{CP}$, crude protein; NDF, neutral detergent fiber; ADF, acid detergent fiber $\mathrm{ADL}$, acid detergent lignin; WSC, water soluble carbohydrates; LAB, lactic acid bacteria; CFU, colony forming units; "/", the detection was not performed; CLL, Cyperus esculentus L. leaves; S1, Sample 1 (mixed with canola straw at a ratio of 4:1); S2, Sample 2 (wilted for $8 \mathrm{~h}$ ).

\subsection{Effect of Additives on Silage Quality and Microbial Population of CLL Silages}

As listed in Table 2, the additives significantly affected fermentation quality, chemical composition, and microbial population in both the S1 and S2 groups after 60 days of ensiling. In the $\mathrm{S} 1$ group, the $\mathrm{pH}$ value was significantly lower in the LM than in the CK (4.09 vs. $5.66, p<0.01)$. A similar phenomenon was observed in the S2 group (3.91 vs. 5.84 of WLM vs. WCK, $p<0.01)$. Acetic acid and lactic acid were the predominant fermentation end products of CLL silage after 60 days of ensiling, followed by ethanol. The contents of lactic acid were $97.78 \mathrm{~g} / \mathrm{kg}$ DM and $146.33 \mathrm{~g} / \mathrm{kg}$ DM in the LM and WLM, respectively, and none was detected in CK and WCK. Neither butyric acid nor propanoic acid were detected. Additionally, the contents of ammonia-N significantly decreased by $42.28 \%$ and $71.2 \%$ in the S1 and S2 groups, respectively $(p<0.01)$. In the S1 group, LM had a higher FC value (36.83 vs. 36.01$)$; in the S2 group, WLM also had a higher FC value (37.61 vs. 31.94). This indicated that the additives had promoted the fermentation quality of CLL silage.

Table 2. Effects of additives on CLL silage quality and microbial population after 60 days of storage.

\begin{tabular}{|c|c|c|c|c|c|c|}
\hline \multirow{2}{*}{ Item } & \multicolumn{3}{|c|}{ S1 Group } & \multicolumn{3}{|c|}{ S2 Group } \\
\hline & CK & LM & $p$ Value & WCK & WLM & $p$ Value \\
\hline \multicolumn{7}{|c|}{ The fermentation quality } \\
\hline $\mathrm{pH}$ value & $5.66 \pm 0.18^{a}$ & $4.09 \pm 0.06^{b}$ & $<0.01$ & $5.84 \pm 0.02^{\mathrm{a}}$ & $3.91 \pm 0.01^{\mathrm{b}}$ & $<0.01$ \\
\hline Lactic acid (g/kg DM) & ND & $97.78 \pm 24.05$ & $<0.01$ & ND & $146.33 \pm 8.98$ & $<0.01$ \\
\hline Acetic acid (g/kg DM) & $14.00 \pm 2.10^{b}$ & $146.34 \pm 13.74^{\mathrm{a}}$ & $<0.01$ & $18.67 \pm 1.97^{b}$ & $215.00 \pm 2.83^{\mathrm{a}}$ & $<0.01$ \\
\hline Ethanol (g/kg DM) & $17.00 \pm 1.63^{a}$ & $10.17 \pm 1.94^{b}$ & $<0.01$ & $19.67 \pm 5.35$ & ND & $<0.01$ \\
\hline Ammonia-N (g/kg DM) & $2.26 \pm 0.12^{\mathrm{a}}$ & $1.30 \pm 0.20^{b}$ & $<0.01$ & $5.66 \pm 0.49^{\mathrm{a}}$ & $1.63 \pm 0.32^{b}$ & $<0.01$ \\
\hline $\mathrm{BC}(\mathrm{meq} / 100 \mathrm{~g} \mathrm{DM})$ & $19.79 \pm 1.29$ & $22.83 \pm 1.84$ & 0.19 & $21.55 \pm 0.06$ & $18.45 \pm 0.56$ & 0.02 \\
\hline FC & $36.01 \pm 1.30$ & $36.83 \pm 0.27$ & 0.48 & $31.94 \pm 2.74$ & $37.61 \pm 2.61$ & 0.17 \\
\hline \multicolumn{7}{|c|}{ Chemical composition } \\
\hline $\mathrm{DM} \%$ & $36.88 \pm 0.02$ & $37.89 \pm 0.02$ & 0.31 & $32.74 \pm 0.01^{b}$ & $37.20 \pm 0.03^{a}$ & $<0.01$ \\
\hline $\mathrm{CP}(\% \mathrm{DM})$ & $8.21 \pm 0.38^{b}$ & $9.60 \pm 0.10^{a}$ & $<0.01$ & $12.17 \pm 0.57^{b}$ & $13.35 \pm 0.17^{a}$ & $<0.01$ \\
\hline NDF (\%DM) & $63.68 \pm 1.89$ & $61.78 \pm 1.93$ & 0.21 & $55.75 \pm 1.06^{\mathrm{a}}$ & $51.70 \pm 1.88^{b}$ & 0.01 \\
\hline $\mathrm{ADF}(\% \mathrm{DM})$ & $43.95 \pm 1.06$ & $41.82 \pm 2.51$ & 0.17 & $30.68 \pm 0.48^{a}$ & $28.69 \pm 0.32^{b}$ & $<0.01$ \\
\hline ADL (\%DM) & $8.95 \pm 0.75$ & $8.62 \pm 0.84$ & 0.57 & $3.89 \pm 0.37$ & $3.63 \pm 0.28$ & 0.30 \\
\hline WSC (\%DM) & $0.39 \pm 0.05^{b}$ & $0.71 \pm 0.04^{\mathrm{a}}$ & $<0.01$ & $0.63 \pm 0.20^{b}$ & $1.01 \pm 0.08^{\mathrm{a}}$ & 0.01 \\
\hline RFV & $79.93 \pm 3.61$ & $84.92 \pm 5.39$ & 0.17 & $108.5 \pm 2.51^{b}$ & $119.87 \pm 4.94^{\mathrm{a}}$ & $<0.01$ \\
\hline \multicolumn{7}{|c|}{ Cultivable microbial population $\left(\log _{10} \mathrm{CFU} / \mathrm{g} \mathrm{FM}\right)$} \\
\hline LAB & $3.95 \pm 2.21^{b}$ & $5.54 \pm 0.15^{\mathrm{a}}$ & $<0.01$ & $2.04 \pm 2.36^{\mathrm{b}}$ & $5.38 \pm 0.14^{\mathrm{a}}$ & $<0.01$ \\
\hline Aerobes & $4.39 \pm 0.12$ & $2.37 \pm 1.84^{b}$ & $<0.01$ & $4.22 \pm 0.03^{a}$ & $1.17 \pm 1.61^{b}$ & $<0.01$ \\
\hline
\end{tabular}

$\mathrm{CK}$, mixed with canola straw without additives; LM, ensiled with additives; WCK, wilted for $8 \mathrm{~h}$ without additives; WLM, wilted for $8 \mathrm{~h}$ and ensiled with additives; $\mathrm{DM}$, dry matter; $\mathrm{CP}$, crude protein; NDF, neutral detergent fiber; $\mathrm{ADF}$, acid detergent fiber; $\mathrm{ADL}$, acid detergent lignin; WSC, water soluble carbohydrates; RFV, relative feed value; $B C$, buffering capacity; FC, fermentation coefficient; LAB, lactic acid bacteria; CFU, colony forming units; ND, not detected. S1, Sample 1 (mixed with canola straw at a ratio of 4:1); S2, Sample 2 (wilted for 8 h). Means \pm SD within the same row with different letters is significantly different $(p<0.05)$. 
The additives significantly improved the nutritive quality of CLL silage. The DM content after ensiling significantly increased in the WLM than that in the WCK $(32.74 \%$ vs. $37.20 \%, p<0.01)$, a similar trend was also found in the LM than that in the CK $(36.88 \%$ vs. $37.89 \%, p=0.31)$. Compared to the WCK, the NDF, ADF and ADL contents were obviously decreased in the WLM. Thus, the WLM had higher RFV than the WCK $(p<0.01)$. The similar results were found in S1 group although there is no significance. The CP contents increased by $16.93 \%$ and $9.70 \%$ in the S1 group and S2 group, respectively $(p<0.01)$, the WSC content also increased by $82.05 \%$ and $60.32 \%$ in the S1 and S2 groups, respectively $(p<0.01)$.

Table 2 also displays the culturable microorganism detected in the S1 and S2 groups. The LAB levels both significantly increased to over $10^{5} \mathrm{CFU} / \mathrm{g}$ FM and the aerobe numbers decreased to below $10^{3} \mathrm{CFU} / \mathrm{g}$ FM $(p<0.01)$ due to the additives. Mold and yeast were not detected in any samples.

\subsection{Effects of the Additives on the Microbial Communities of CLL Silages}

High-throughput sequencing of $16 \mathrm{~S}$ rDNA gene amplicons demonstrates how bacterial communities are affected after systematic ensiling. The alpha diversity of all samples is exhibited in Table 3. The coverage values of all samples exceeded 0.99 , suggesting that the sequencing depth was adequate to detect most bacteria. Compared with the controls in both groups, the treatment groups had both lower Chao and Shannon indexes, reflecting decreases in bacterial diversity due to dominant microorganisms that could have been replaced through cluster analysis. The variance in the microbial population in the S1 and S2 groups can be illustrated by principal component analysis (PCA). CK and LM can both be separated, while a similar discrepancy was also found in the S2 group (Figure S1). These results indicate that the additives significantly affected the bacterial community of CLL silage.

Table 3. Alpha diversity of the bacterial community in the S1 and S2 groups after 60 days of ensiling.

\begin{tabular}{ccccccc}
\hline \multirow{2}{*}{ Item } & \multicolumn{3}{c}{ S1 Group } & \multicolumn{3}{c}{ S2 Group } \\
\cline { 2 - 7 } & CK & LM & $p$ Value & WCK & WLM & $p$ Value \\
\hline Shannon & $1.99 \pm 0.08^{\mathrm{a}}$ & $0.58 \pm 0.03^{\mathrm{b}}$ & $<0.01$ & $2.00 \pm 0.24^{\mathrm{a}}$ & $0.83 \pm 0.08^{\mathrm{b}}$ & $<0.01$ \\
Simpson & $0.25 \pm 0.02^{\mathrm{b}}$ & $0.69 \pm 0.02^{\mathrm{a}}$ & $<0.01$ & $0.29 \pm 0.06^{\mathrm{b}}$ & $0.55 \pm 0.05^{\mathrm{a}}$ & 0.02 \\
ACE & $240.46 \pm 11.46$ & $209.68 \pm 16.93$ & 0.13 & $207.95 \pm 21.69$ & $159.66 \pm 10.51$ & 0.13 \\
Chao 1 & $234.94 \pm 11.42$ & $177.19 \pm 18.94$ & 0.03 & $190.38 \pm 17.50$ & $136.69 \pm 10.24$ & 0.07 \\
Coverage & 0.99 & 0.99 & 0.18 & 0.99 & 0.99 & 0.24 \\
\hline
\end{tabular}

$\mathrm{CK}$, mixed with canola straw without additives; LM, ensiled with additives; WCK, wilted for $8 \mathrm{~h}$ without additives; WLM, wilted for $8 \mathrm{~h}$ and ensiled with additives. S1, Sample 1 (mixed with canola straw at a ratio of 4:1); S2, Sample 2 (wilted for $8 \mathrm{~h}$ ). Means \pm SD within the same row with different letters is significantly different $(p<0.05)$.

Figure 1 displays the bacterial communities at the genus and species level of the S1 and S2 groups after 60 days of ensiling. In the control groups (CK and WCK), Enterobacter was the most abundant genus, comprising approximately $77.51 \%$ and $50.16 \%$ of the entire communities, respectively. Kosakonia and Enterococcus were also present in the materials before ensiling. However, the relative abundance of Enterobacter significantly decreased or even disappeared in treatments (LM and WLM). Lactobacillus is a desirable genus that became the most prevalent genus; its abundance reached nearly $90 \%$ of the total population. Additionally, several spore-forming bacteria, such as Clostridium and Bacillus, were also detected in raw materials. These are always associated with aerobic deterioration. These results implied that the additives have obviously modified the fermented microbiota of CLL silage. 

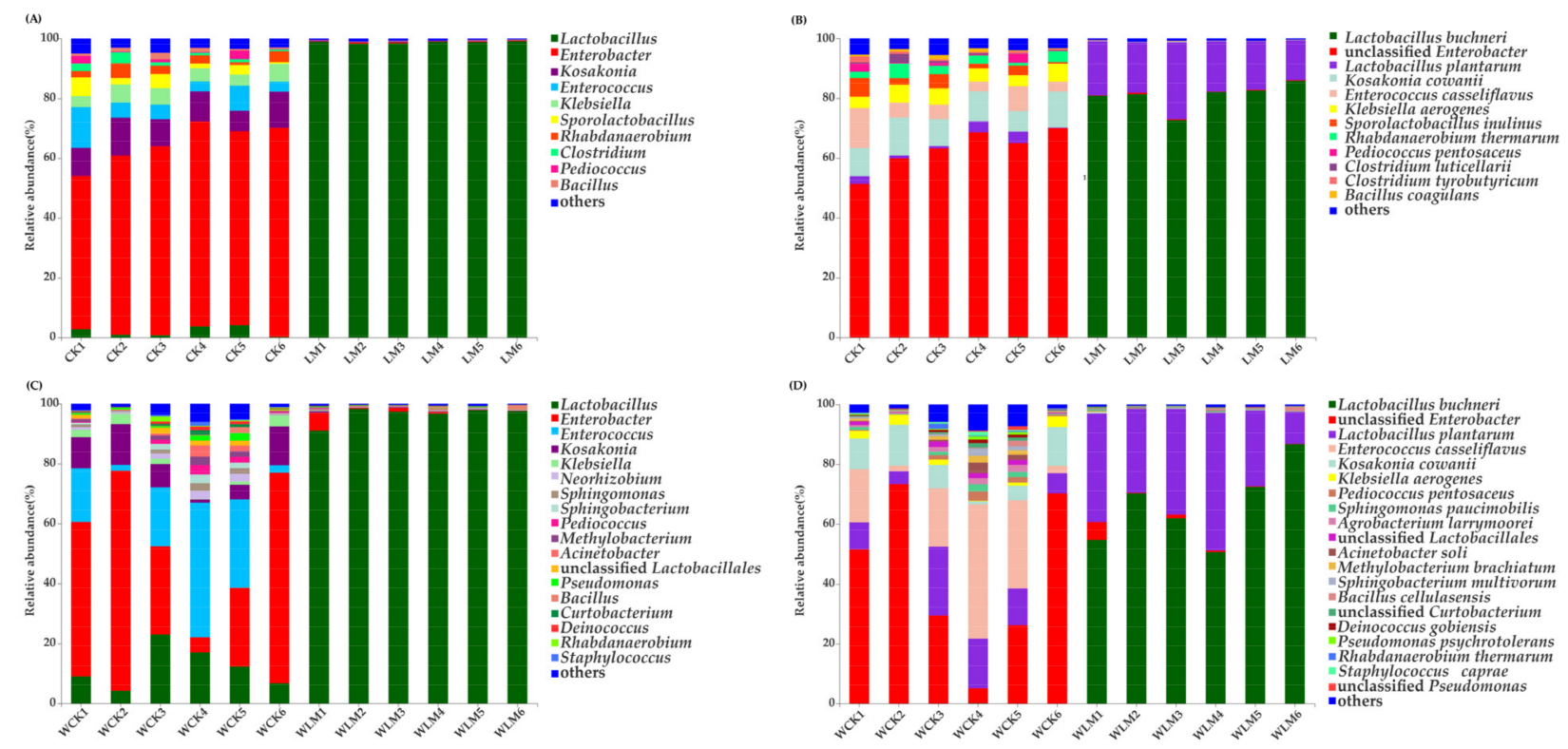

Figure 1. Relative abundances of bacteria communities in CLL silage. (A): the genus level of the S1 group; (B): the species level of the S1 group; (C): the genus level of the S2 group; (D): the species level of the S2 group. S1, Sample 1 (mixed with canola straw at a ratio of 4:1); S2, Sample 2 (wilted for $8 \mathrm{~h}$ ). CK, mixed with rapeseed straw without additives; LM, ensiled with additives; WCK, wilted for $8 \mathrm{~h}$ without additives; WLM, wilted for $8 \mathrm{~h}$ and ensiled with additives.

\subsection{Metabolomics Profiles of CLL Silages Ensiling for 60 Days}

Total 891 substances were detected by analyzing the retention time and mass:charge ratio of all ions found in the chromatograms of the CLL silage samples. Of these, 361 metabolites in the S1 group and 406 substances in the S2 group and their relative concentrations were identified and annotated based on the Human Metabolome Database (HMDB). PCA of positive and negative (Figure S2) demonstrated that there were clear differences between CK, LM, and QC (Quality Control) in the S1 group. Similarly, WCK, WLM, and QC were also clearly separated in the $\mathrm{S} 2$ group, indicating that there are differences between samples within treatments.

Table 4 displays the relative concentration of certain metabolites with biological functions in the S1 and S2 groups. In the S1 group, LM has more cinnamic acids and derivatives (such as sinapic acid, caffeic acid, and 2-hydroxycinnamic acid), flavonoids (such as the quercetin, theaflavic acid, and isorhamnetin), ferulic acid, and zeranol compared to CK. All of these have antioxidant properties and antibacterial activities. Toxic compounds such as hypoxanthine, 7a-hydroxy-5b-cholanic acid, and 7-epi-Jasmonic acid decreased in the LM compared to the CK. In the S2 group, higher contents of carboxylic acids and derivatives (such as valyl-isoleucine, threoninyl-isoleucine, glycyl-isoleucine, asparaginyl-isoleucine), flavonoids (such as kaempferol 3-(2"-rhamnosylrutinoside) and 7galloylcatechin), organooxygen compounds (such as 1,3-dicaffeoylquinic acid, chlorogenic acid, and 3-O-feruloylquinic acid), ferulic acid, and D-(+)-3-phenyllactic acid were seen in WLM than in WCK, while the contents of compounds with a foul smell (such as grandisine III and piperidine) decreased.

In summary, the contents of metabolites with beneficial biofunctional activities (such as flavonoids, cinnamic acids and derivatives, steroids and steroid derivatives, and ferulic acid) increased in LM and WLM in the S1 and S2 groups, compared to the control groups (CK and WCK). The type of flavonoids in the S1 group increased more than in the S2 group, while more dipeptide and organooxygen compounds were observed in the S2 group. 
Table 4. Relative concentration and fold-changes in differential metabolites in S1 and S2 groups after 60 days of ensiling.

\begin{tabular}{|c|c|c|c|c|c|c|c|}
\hline \multirow{2}{*}{\multicolumn{2}{|c|}{ Metabolite Name }} & \multicolumn{3}{|c|}{ S1 Group } & \multicolumn{3}{|c|}{ S2 Group } \\
\hline & & CK & LM & Fold Change & WCK & WLM & Fold Change \\
\hline $\begin{array}{l}\text { Benzene and } \\
\text { substituted } \\
\text { derivatives }\end{array}$ & Syringic acid & $12.42 \pm 0.18^{b}$ & $14.29 \pm 0.55^{\mathrm{a}}$ & $1.87 \pm 0.53$ & $13.28 \pm 0.30^{\mathrm{b}}$ & $15.3 \pm 0.13^{\mathrm{a}}$ & $2.02 \pm 0.31$ \\
\hline \multirow{5}{*}{$\begin{array}{l}\text { Carboxylic acids } \\
\text { and derivatives }\end{array}$} & \multirow{5}{*}{$\begin{array}{c}\text { L-Tyrosine } \\
\text { Valyl-Isoleucine } \\
\text { Threoninyl-Isoleucine } \\
\text { Glycyl-Isoleucine } \\
\text { Asparaginyl- } \\
\text { Isoleucine }\end{array}$} & $6.52 \pm 0.83^{b}$ & $9.89 \pm 0.14^{\mathrm{a}}$ & $3.37 \pm 0.88$ & ND & ND & ND \\
\hline & & ND & ND & ND & $2.92 \pm 0.65^{b}$ & $9.87 \pm 0.15^{\mathrm{a}}$ & $3.50 \pm 0.61$ \\
\hline & & ND & ND & ND & $1.55 \pm 2.33^{b}$ & $9.63 \pm 0.15^{\mathrm{a}}$ & $8.08 \pm 2.34$ \\
\hline & & ND & ND & ND & $5.18 \pm 2.18^{b}$ & $10.85 \pm 0.11^{\mathrm{a}}$ & $5.66 \pm 2.14$ \\
\hline & & ND & ND & ND & $6.29 \pm 0.65^{b}$ & $10.50 \pm 0.12^{\mathrm{a}}$ & $4.20 \pm 0.74$ \\
\hline \multirow{4}{*}{$\begin{array}{l}\text { Cinnamic acids } \\
\text { and derivatives }\end{array}$} & \multirow{4}{*}{$\begin{array}{c}\text { Sinapic acid } \\
\text { Caffeic acid } \\
\text { 2-hydroxycinnamic } \\
\text { acid } \\
\text { M-Coumaric acid }\end{array}$} & $9.53 \pm 1.29$ & $11.09 \pm 0.70$ & $1.56 \pm 1.86$ & $2.92 \pm 0.65^{b}$ & $9.87 \pm 0.15^{\mathrm{a}}$ & $6.96 \pm 0.77$ \\
\hline & & $10.04 \pm 0.11$ & $11.81 \pm 0.79$ & $1.78 \pm 0.82$ & $10.60 \pm 0.49^{b}$ & $13.53 \pm 0.12^{\mathrm{a}}$ & $2.93 \pm 0.48$ \\
\hline & & $12.25 \pm 0.90^{\mathrm{b}}$ & $14.76 \pm 0.12^{a}$ & $2.51 \pm 0.90$ & ND & ND & ND \\
\hline & & $8.18 \pm 0.80^{b}$ & $11.61 \pm 0.29^{a}$ & $3.42 \pm 0.94$ & $9.27 \pm 0.76^{b}$ & $12.64 \pm 0.08^{a}$ & $3.38 \pm 0.73$ \\
\hline Punicic acid & Punicic acid & $14.93 \pm 0.28$ & $15.25 \pm 0.11$ & $0.32 \pm 0.27$ & ND & ND & ND \\
\hline \multirow{6}{*}{ Flavonoids } & \multirow{6}{*}{$\begin{array}{c}\text { Quercetin } \\
\text { Theaflavic acid } \\
\text { Isorhamnetin } \\
\text { Isovitexin } \\
\text { 7-galloylcatechin } \\
\text { Kaempferol 3-(2"- } \\
\text { rhamnosylrutinoside) }\end{array}$} & $12.21 \pm 1.40$ & $14.14 \pm 0.63$ & $1.94 \pm 1.68$ & ND & ND & ND \\
\hline & & $14.73 \pm 0.29$ & $15.27 \pm 0.20$ & $0.54 \pm 0.38$ & ND & ND & ND \\
\hline & & $14.21 \pm 1.13$ & $15.52 \pm 0.31$ & $1.31 \pm 1.21$ & ND & ND & ND \\
\hline & & $14.27 \pm 0.33$ & $14.76 \pm 0.13$ & $0.49 \pm 0.40$ & ND & ND & ND \\
\hline & & ND & ND & ND & $2.96 \pm 1.54^{b}$ & $10.24 \pm 0.41^{\mathrm{a}}$ & $7.27 \pm 1.76$ \\
\hline & & ND & ND & ND & $9.31 \pm 0.79^{b}$ & $13.64 \pm 0.29^{\mathrm{a}}$ & $4.32 \pm 0.67$ \\
\hline Imidazopyrimidines & Hypoxanthine & $12.34 \pm 0.28$ & $10.95 \pm 0.15$ & $-1.39 \pm 0.37$ & $12.50 \pm 0.39^{a}$ & $10.09 \pm 0.20^{b}$ & $-2.40 \pm 0.49$ \\
\hline $\begin{array}{l}\text { Macrolides and } \\
\text { analogues }\end{array}$ & Zeranol & $8.84 \pm 0.53^{b}$ & $10.48 \pm 0.78^{a}$ & $1.64 \pm 0.84$ & ND & ND & ND \\
\hline \multirow{5}{*}{$\begin{array}{l}\text { Organooxygen } \\
\text { compounds }\end{array}$} & $\begin{array}{c}\text { 1,3-dicaffeoylquinic } \\
\text { acid }\end{array}$ & ND & ND & ND & $11.39 \pm 0.94$ & $12.35 \pm 0.36$ & $0.96 \pm 0.92$ \\
\hline & $\begin{array}{c}\text { 3-O- } p \text { - } \\
\text { Coumaroylquinic } \\
\text { acid }\end{array}$ & ND & ND & ND & $10.07 \pm 0.24^{\mathrm{b}}$ & $12.43 \pm 0.54^{\mathrm{a}}$ & $2.36 \pm 0.43$ \\
\hline & \multirow{3}{*}{$\begin{array}{l}\text { Chlorogenic acid } \\
\mathrm{N} \text {-di-Demethyl } \\
\text { roxithromycin } \\
\text { 3-O-feruloylquinic } \\
\text { acid }\end{array}$} & ND & ND & ND & $11.73 \pm 0.54^{\mathrm{b}}$ & $14.67 \pm 0.57^{\mathrm{a}}$ & $2.95 \pm 0.72$ \\
\hline & & ND & ND & ND & $9.52 \pm 1.47^{b}$ & $11.59 \pm 0.58^{a}$ & $2.07 \pm 1.87$ \\
\hline & & ND & ND & ND & $7.17 \pm 1.38^{\mathrm{b}}$ & $10.71 \pm 0.75^{\mathrm{a}}$ & $3.54 \pm 1.51$ \\
\hline $\begin{array}{l}\text { Phenylpropanoic } \\
\text { acids }\end{array}$ & $\begin{array}{l}\text { Hydroxyphenyllactic } \\
\text { acid }\end{array}$ & ND & ND & ND & $10.34 \pm 0.42^{b}$ & $12.18 \pm 0.14^{\mathrm{a}}$ & $1.84 \pm 0.45$ \\
\hline \multirow{2}{*}{ Prenol lipids } & Annoglabasin E & $8.02 \pm 0.94$ & $9.96 \pm 0.33$ & $1.94 \pm 1.12$ & $6.36 \pm 0.38^{b}$ & $10.56 \pm 0.55^{\mathrm{a}}$ & $4.20 \pm 0.40$ \\
\hline & Betulin & ND & ND & ND & $7.08 \pm 1.61^{b}$ & $11.02 \pm 0.92^{\mathrm{a}}$ & $4.02 \pm 1.82$ \\
\hline Piperidine & Piperidine & ND & ND & ND & $14.64 \pm 0.21$ & $14.39 \pm 0.10$ & $-0.25 \pm 0.18$ \\
\hline $\begin{array}{l}\text { Steroids and } \\
\text { steroid } \\
\text { derivatives }\end{array}$ & $\begin{array}{l}\text { 7a-hydroxy-5b- } \\
\text { cholanic } \\
\text { acid }\end{array}$ & $13.19 \pm 0.66$ & $11.87 \pm 0.97$ & $-1.32 \pm 1.41$ & $3.97 \pm 0.20$ & $3.57 \pm 0.30$ & $-0.40 \pm 0.10$ \\
\hline $\begin{array}{l}\text { Quinolines and } \\
\text { derivatives }\end{array}$ & Grandisine III & ND & ND & ND & $11.94 \pm 0.74$ & $10.05 \pm 0.54$ & $-1.88 \pm 0.91$ \\
\hline \multirow{3}{*}{ Others } & \multirow{3}{*}{$\begin{array}{c}\text { Ferulic acid } \\
\text { D-(+)-3-phenyllactic } \\
\text { acid } \\
\text { 7-epi-Jasmonic acid }\end{array}$} & $11.47 \pm 0.69$ & $13.31 \pm 0.20$ & $1.84 \pm 0.63$ & $12.26 \pm 0.63$ & $13.09 \pm 0.14$ & $0.83 \pm 0.71$ \\
\hline & & $13.66 \pm 0.21$ & $14.71 \pm 0.06$ & $1.05 \pm 0.26$ & $12.67 \pm 0.52^{b}$ & $14.86 \pm 0.06^{\mathrm{a}}$ & $2.19 \pm 0.53$ \\
\hline & & $12.15 \pm 1.06^{\mathrm{a}}$ & $8.46 \pm 0.48^{b}$ & $-3.69 \pm 1.42$ & $12.77 \pm 3.24^{\mathrm{a}}$ & $2.42 \pm 1.23^{\mathrm{b}}$ & $-10.36 \pm 3.24$ \\
\hline
\end{tabular}

The relative concentration of each metabolite is an average of the data from six biological replicates. FC, fold-changes, positive value means upregulation; negative value means downregulation. CK, mixed with canola straw without additives; LM, ensiled with additives; WCK, wilted for $8 \mathrm{~h}$ without additives; WLM, wilted for $8 \mathrm{~h}$ and ensiled with additives; "ND", not detected. "Others" means there is no corresponding classification in the Human Metabolome Database (HMDB). Means \pm SD within the same row with different letters is significantly different $(p<0.05)$.

\subsection{Correlations between Main Microorganisms and Metabolites in CLL Silage}

A Spearman correlation heat map was generated at the species level to display the association between differential metabolites and dominant bacteria in S1 and S2 groups respectively (Figures 2 and 3). Metabolites positively correlated with LAB were negatively correlated with undesirable bacteria during the ensiling process. In the S1 group, ferulic acid, $m$-Coumaric acid, and $p$-Coumaric acid were positively correlated with L. plantarum and L. buchneri, and were negatively correlated with the unclassified Enterobacter, Pediococcus pentosaceus, unclassified Pantoea, Streptomyces albidoflavus, and unclassified Curtobacterium. In the S2 group, 7-galloylcatechin, chlorogenic acid, and 3-O-p-Coumaroylquinic acid were positively correlated with $L$. plantarum and L. buchneri, and were negatively 
correlated with the unclassified Lactobacillales, Enterococcus casseliflavus, Kosakonia cowanii and unclassified Enterobacter, Klebsiella aerogenes, and Agrobacterium larrymoorei.

In summary, metabolites with biological functions tended to positively correlated with LAB and negatively correlated with undesirable bacteria.

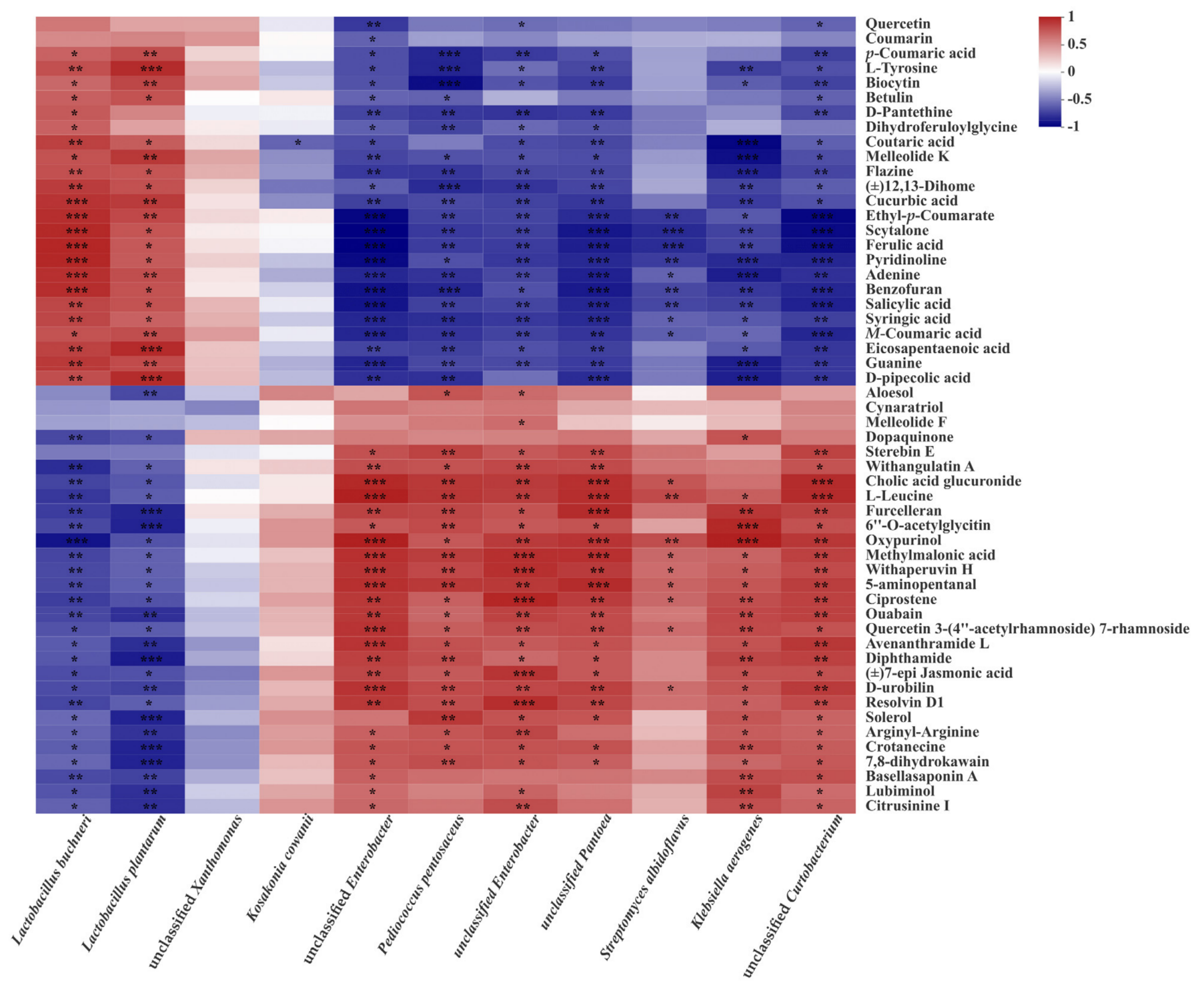

Figure 2. Spearman correlations between main bacteria species and differentially presented metabolites in S1 group. The differentially presented metabolites during fermentation were screened by OPLS-DA; $p$-values are shown as ${ }^{*} p \leq 0.05$; ${ }^{* *} p \leq 0.01 ; * * * 0.001$ 


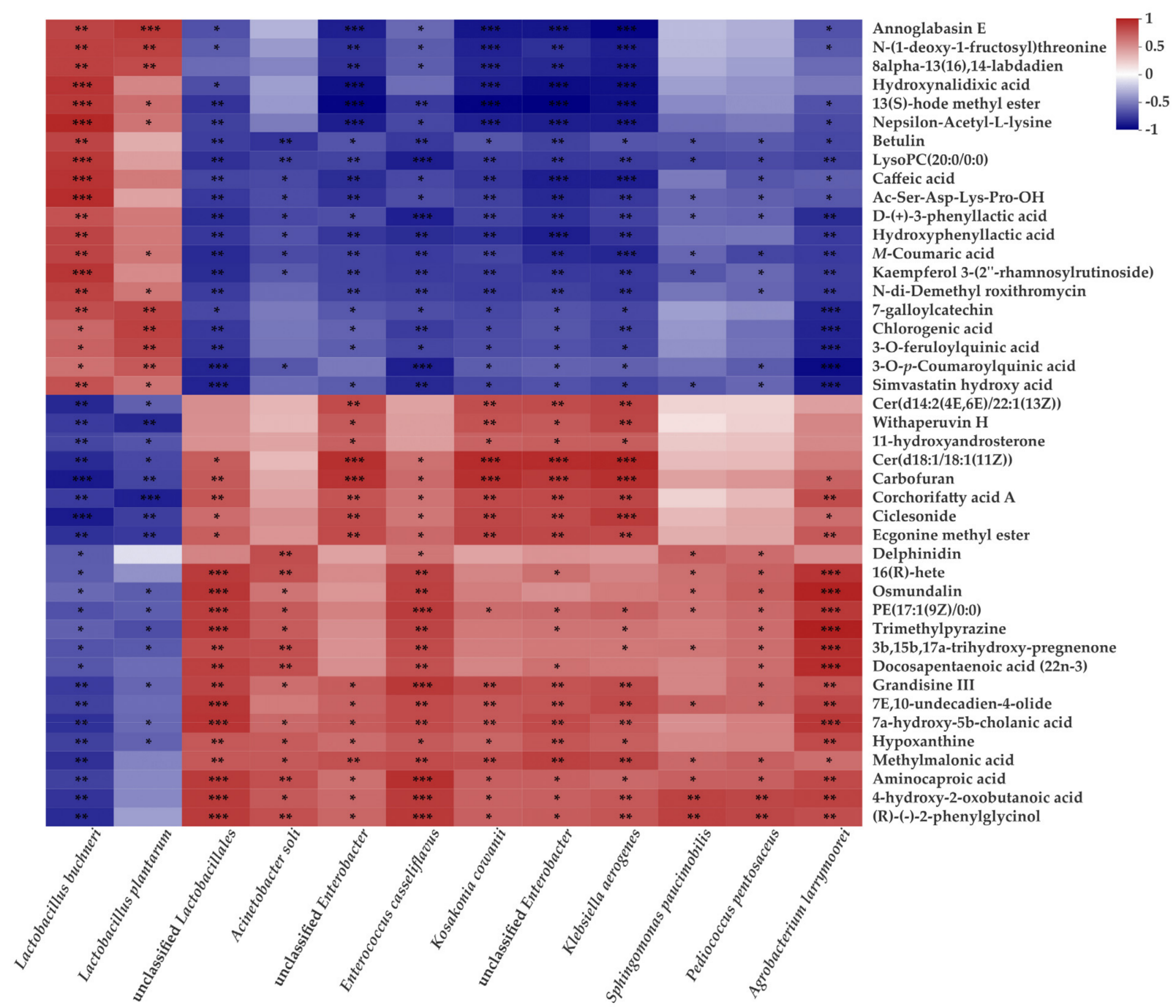

Figure 3. The differentially presented metabolites during fermentation were screened by OPLS-DA; $p$-values are shown as ${ }^{*} p \leq 0.05 ;{ }^{* *} p \leq 0.01 ;{ }^{* * *} p \leq 0.001$.

\section{Discussion}

Agricultural by-products are important sources of feed for livestock, especially when livestock cannot acces high-quality roughage. Ensiling is a method typically used to prolong the storage time of forage by using LAB fermentation under anaerobic conditions [13]. As such, a better understanding of the metabolomics and bacterial community during the fermentation process could provide powerful evidence for making high-quality silages [26]. Ensiling is a complex process that is affected by several factors, such as the DM content of materials, WSC content and epiphytic microbiota of materials. Low moisture content helps condense WSC content, promoting lactic acid fermentation and suppressing the production of ammonia-N [27]. In addition, abundant WSC content affects the quality of fermentation, while WSC contents exceeding 5\% DM typically produce silage of sufficient quality [13]. Molasses is considered the most effective and economically fermentable substrate [13]. Concerning epiphytic microbiota, both Cai et al. [28] and Oliveira et al. [29] stressed that the forage would only be well-preserved if the level of LAB exceeded $10^{5} \mathrm{CFU} / \mathrm{g}$ FM. During the ensiling process, $\mathrm{LAB}$ can produce lactic acid, hydrogen peroxide, and antimicrobial substances to inhibit undesirable microorganisms to reduce nutritional loss [14]. Otherwise, DM recovery decreases while ammonia- $\mathrm{N}$ concentration increases [28-30]. While aerobes are undesirable, they typically appear when the silo opens and are usually associated with high DM loss and decreased aerobic stability [30]. The high moisture content, low WSC 
content, low levels of epiphytic LAB, and presence of harmful microorganisms indicates that the ensiling process of fresh CLL must be controlled only if mixed with absorbent or wilted to increase DM content and inoculated with LAB and extra WSC.

Fermentation quality significantly improved after 60 days of ensiling with compound $\mathrm{LAB}$ additives. The $\mathrm{pH}$ values of additives treated CLL silage were below 4.2, which could be attributed to higher organic acid content produced by LAB. Increased levels of LAB resulted in significant increases in lactic acid and acetic acid contents. Lactic acid is the main product of $\mathrm{LAB}$ and has a $\mathrm{pKa} 3.86$, which is the main organic acid affecting $\mathrm{pH}$ value and promotes the reductions in $\mathrm{pH}$ value observed in ensiled material [13]. However, acetic acid was the dominant fermentation product in both the S1 and S2 groups and likely resulted from the abundant heterofermentative pattern favored by L. buchneri, which aligns with the findings of Kung et al. [31], Zhang et al. [32] and Wang et al. [18] reported that acetic acid has significant antifungal properties, which are crucial for improving the aerobic stability of silage. Mold and yeast were not detected in all samples, which could be due to low $\mathrm{pH}$ values. As Li et al. [33] reported, anaerobic conditions and organic acid can inhibit yeast growth, especially after long storage periods. Additionally, ammonia-N contents decreased in both LM and WLM, which typically occurs during the ensiling process and is a result of the fermentation of Clostridium or the activity of plant protease [34]. In this study, Clostridium was found in CK/WCK instead of LM/WLM; as such, decreased ammonia- $\mathrm{N}$ could be attributed to the inhibited growth of Clostridium. Herrmann et al. [35] demonstrates that a raw material is suited for ensiling if it contains sufficient WSC as fermentable substrate, a low BC to allow rapid for acidification, and sufficient DM content. Therefore, the ensilability of silage raw material could be assessed by FC [35]. Weissbach et al. [25] proposed that if the FC value reaches 35, it means that high-quality silage is produced. In this study, the FC value in LM and WLM both exceed 35 and were higher than WCK and CK. The FC value in WLM was higher than in LM, suggesting that wilting may be a better way to promote fermentation than absorbents (canola straw).

The nutritional quality also improved in compound LAB additive-treated CLL silage. $\mathrm{DM}$ is a vital measure of the organic matter accumulation of silage, and increasing DM content maximizes the efficiency of the ensiling process [36]. The DM contents increased in both the $\mathrm{S} 1$ and $\mathrm{S} 2$ groups. The NDF, ADF, and ADL contents represent the digestibility of cellulose and hemicellulose by ruminant animals, which affects digestibility and feed intake [37]. Compared with CK and WCK, relatively low contents of NDF, ADF, and ADL were observed in LM and WLM. This indicates that LM and WLM had low lignocellulosic structures and became highly digestible. The contents of NDF and ADF were not significantly affected in the S1 group, which could be attributed to the addition of canola straw in the S1 group, making the fermentation effect inferior to that in the S2 group. RFV is widely acknowledged to predict forage quality [38]. The RFV of WCK and WLM exceeded that of CK and WCK, which could account for the lower content of ADF, $\mathrm{NDF}$, and the higher content of WSC, which was used to calculate and parameterize the RFV. Alfalfa is a high-quality forage plant with a high protein content; it is cultivated and used for animal feed all over the world [14]. Ertekin et al. [37] reported that the RFV of alfalfa silage (harvested at 50\% flowering period) could reach 107.09. The RFV of WCK and WLM exceeded that of alfalfa (108.5 and 119.87, respectively), suggesting that wilted CLL has great potential as a high-quality forage material. In addition, the WSC and CP contents were higher in the wilted group (S2 group), especially in WLM (compound LAB additives treated), indicating that the CLL silage were well-preserved and digestible for additives. Thus, accounting for chemical composition, the S2 group performed better than the S1 group.

High throughput analyses produce data sufficient for taxonomically classifying microbiota identified during ensiling [13]. However, no studies have assessed the bacterial community in CLL silage. The alpha diversity values obtained by this study demonstrate that the bacterial community saw decreases in richness and diversity compared to the con- 
trol groups, which was similar to the results of $\mathrm{Xu}$ et al. [39]. The main genus in the control groups (CK and WCK) was Enterobacter, followed by Kosakonia, Enterococcus, Klebsiella, Sporolactobacillus, and Sphingomonas. These were defined as undesirable bacteria and were not expected found in silage, for they always competed with LAB and negatively affected silage [30]. After ensiling for 60 days, they were replaced by Lactobacillus, which occupied over $98 \%$ in the S1 group as well as $95.4 \%$ in the S2 group. Lactobacillus can inhibit undesirable microorganisms by producing organic acids and metabolites with antimicrobial activity [40]. Additionally, differences in the microbial community could significantly affect silage quality [22]. In this study, L. buchneri and L. plantarum were the main species found in the CLL silage after ensiling for 60 days. Furthermore, the proportion of L. buchneri exceeded that of L. plantarum, which is similar to what Xu et al. [40] reported in whole crop corn: that inoculation with L. plantarum can promote the growth of L. buchneri and result in more acetic acid production than lactic acid production. Heinl et al. [41] reported that the lactic acid produced by homofermentative $L A B$ could be utilized as the substrate of heterofermentative LAB, which could account for this phenomenon.

The fermentation process entails many types of microorganisms, produces various metabolites, and is extremely complex. As such, a better understanding of the metabolomics and bacterial community during the fermentation process could provide powerful evidence for making high-quality roughage [26]. The Spearman correlation analyzed the main bacteria and the main differential metabolites in CLL silage. Our results demonstrate that the correlation between metabolites and Lactobacillus was opposite from that in the undesirable microorganisms, indicating that Lactobacillus and the undesirable microorganisms competed during CLL ensiling. Furthermore, metabolites with biological activities were always positively associated with Lactobacillus and negatively associated with undesirable microorganisms. In the S1 group, $p$-Coumaric acid, which is a precursor of various phenolic compounds and exerts antioxidant and antimicrobial activities, was positively associated with L. plantarum and L. buchneri [42]. As the major derivatives of $p$-Coumaric acid detected in natural plants with antifungal properties [43], ethyl- $p$-Coumarate was positively correlated with L. plantarum and L. buchneri. Solerol was negatively associated with L. plantarum and L. buchneri and is typically a marker for succinic semialdehyde dehydrogenase, which can cause neurological and cognitive disorders [44]. In the S2 group, betulin is positively associated with L. buchneri, which is an active natural triterpenoid alcohol with antioxidant potential [45]; 7-galloylcatechin is the key precursor that forms gallic acid during anaerobic fermentation [46] and is positively correlated with L. plantarum and L. buchneri. Carbofuran is extremely lethal to mammals due to its anticholinesterase activity [47], it has a significantly negative correlation with L. plantarum and L. buchneri. Additionally, the ferulic acid content increased in LM and WLM. This indicates that the fiber digestibility in the additives treatments is better than in the control since it is typically linked to polysaccharides by ferulic acid ester in plant cell walls, forming a solid protective layer [14]. The up-accumulation of nucleobase and dipeptide was detected, which was consistent with the findings of Guo et al. [26] and Xu et al. [40] that L. buchneri can produce certain amino acids during fermentation. Metabolites with biofunctions (such as corchorifatty acid, osmundain, and furelleran, et al.) were negatively correlated with LAB species, which could be due to sample concentrations that were too low to sufficiently detect, which was similar to the findings of $X u$ et al. [40]. In summary, samples treated with additives (LM/WLM) resulted in the accumulation of certain metabolites with antioxidant properties and antimicrobial activity, including $m$-Coumaric acid, theaflavic acid, quercetin, isorhamnetin, ferulic acid, and 7-galloylcatechin. This caused a reduction in toxic and hazardous substances, including carbofuran and solerol. Admittedly, the Spearman correlation is based on statistics and correlates parameters to obtain a result that represents nothing more than speculation. Even so, the correlations between LAB and the metabolites with biological activities in CLL silage provided clues on screening targeted functional LAB strains for modulating silage fermentation with the aim of obtaining high quality silage. 


\section{Conclusions}

Cyperus esculentus $\mathrm{L}$. by-product could be processed into silage with additives after being mixed with canola straw or wilted. The compound LAB additives produced positive fermentative properties, increased the nutritional value of CLL silage. Additives enhanced the fermentation quality, resulting in low $\mathrm{pH}$ values, high contents of lactic acid and acetic acid, and low ammonia- $\mathrm{N}$ concentrations. The improved nutritional values are reflected in the increased CP and WSC contents in additives treated groups. In the perspective of FC and RFV, the wilting approach is superior to mixing with canola straw. The compound LAB additives also altered the microbiota of CLL silage. The relative abundance of Lactobacillus was enhanced and the relative abundance of undesirable microorganisms, including Clostridium and Enterobacter, was reduced. In CLL silage, substances with antioxidant properties, bacteriostatic activity, and other flavoring agents were detected, all of which typically have a positive relationship with L. buchneri and L. plantarum. As the major species in CLL silage, L. buchneri and L. plantarum might regulate silage fermentation through modifying microbiota and metabolomics. In conclusion, Cyperus esculentus L. by-product could be used as a potential roughage after it is ensiled with compounded LAB additives.

Supplementary Materials: The following are available online at https: / /www.mdpi.com/article/ 10.3390 / fermentation7040273/s1, Figure S1: Principal component analysis (PCA) of metabolic profiles in S1 group (S1 A) and S2 group (S1 B) silage inoculated without (red circle) or with additives (blue triangle) $(n=6)$. S2: Principal component analysis (PCA) of metabolic profiles in S1 (pos: S2.A, neg: S2.B) and S2 (pos: S2 C, neg: S2 D) silage without or with additives. CK, mixed with canola straw without additives; LM ensiled with additives; WCK, wilted for $8 \mathrm{~h}$ without additives; WLM, wilted for $8 \mathrm{~h}$ and ensiled with additives.

Author Contributions: Conceptualization, J.Z. and T.W.; methodology, J.S. and W.S.; software, J.S. and C.M.; validation, J.S., T.W., W.S., C.M. and J.Z.; formal analysis, T.W.; investigation, J.S. and T.W.; resources, T.W.; data curation, J.S., T.W. and W.S.; writing-original draft preparation, J.S., F.H., Y.L.; writing—review and editing, J.S. and T.W.; visualization, T.W.; supervision, J.Z.; project administration, J.Z.; funding acquisition, J.Z. All authors have read and agreed to the published version of the manuscript.

Funding: This research was funded by Strategic Priority Research Program of the Chinese Academy of Sciences (XDA26040201), Key Deployment Project of Chinese Academy of Sciences (KFZD-SW-113).

Institutional Review Board Statement: Not applicable.

Informed Consent Statement: Not applicable.

Data Availability Statement: Data is contained within this article.

Acknowledgments: The authors are grateful to Guangmei Wang of the Yantai Institute of Coastal Zone Research, Chinese Academy of Sciences, for his donation of experimental materials.

Conflicts of Interest: The authors declare no conflict of interest.

\section{References}

1. De Castro, O.; Gargiulo, R.; Del Guacchio, E.; Caputo, P.; De Luca, P. A molecular survey concerning the origin of Cyperus esculentus (Cyperaceae, Poales): Two sides of the same coin (weed vs. crop). Ann. Bot. 2015, 115, 733-745. [CrossRef]

2. Ayeh-Kumi, P.F.; Tetteh-Quarcoo, P.B.; Duedu, K.O.; Obeng, A.S.; Addo-Osafo, K.; Mortu, S.; Asmah, R.H. A survey of pathogens associated with Cyperus esculentus L. (tiger nuts) tubers sold in a Ghanaian city. BMC Res. Notes 2014, 7, 343. [CrossRef]

3. Cortes, C.E.M.; Frigola, A. Quality characteristics of horchata (a Spanish vegetable beverage) treated with pulsed electric field during shelf life. Food Chem. 2005, 91, 319-325. [CrossRef]

4. Qu, P.; Cheng, Z.; Long, C.; Su, M.; Yang, D. Comprehensive development of chufa (Cyperuseslent L. varsatius) s. China Oils Fats 2007, 61-63. (In Chinese)

5. Jing, S.; Wang, S.; Zhong, R.; Zhang, J.; Wu, J.; Tu, Y.; Pu, Y.; Yan, L. Neuroprotection of Cyperus esculentus L. orientin against cerebral ischemia/reperfusion induced brain injury. Neural Regen. Res. 2020, 15, 548-556. [CrossRef]

6. Coskuner, Y.; Ercan, R.; Karababa, E.; Nazlican, A.N. Physical and chemical properties of chufa (Cyperus esculentus L.) tubers grown in the climate region of Turkey. J. Sci. Food Agric. 2002, 82, 625-631. [CrossRef] 
7. Roselló-Soto, E.; Martí-Quijal, F.J.; Cilla, A.; Munekata, P.E.S.; Lorenzo, J.M.; Remize, F.; Barba, F.J. Influence of temperature, solvent and $\mathrm{pH}$ on the selective extraction of phenolic compounds from tiger nuts by-products: Triple-TOF-LC-MS-MS characterization. Molecules 2019, 24, 797. [CrossRef] [PubMed]

8. Zhao, G.; Ju, Z.; Chai, J.; Jiao, T.; Jia, Z.; Casper, D.; Zeng, L.; Wu, J. Effects of silage additives and varieties on fermentation quality, aerobic stability, and nutritive value of oat silage. J. Anim. Sci. 2018, 96, 3151-3160. [CrossRef] [PubMed]

9. Zhang, Y.; Wang, X.; Dai, J.; Meng, X.; Zhao, Y.; Li, Z.; Hu, Y.; Cui, Z. Construction and effect of lactic acid bacteria in oat silage and mechanism at low temperature. Trans. CSAE 2019, 35, 308-314. (In Chinese)

10. Wang, Y.; McAllister, T.A.; Acharya, S. Condensed tannins in sainfoin: Composition, concentration, and effects on nutritive and feeding value of sainfoin forage. Crop Sci. 2015, 55, 13-22. [CrossRef]

11. Tao, Y.; Sun, Q.; Li, F.; Xu, C.; Cai, Y. Comparative analysis of ensiling characteristics and protein degradation of alfalfa silage prepared with corn or sweet sorghum in semiarid region of Inner Mongolia. Anim. Sci. J. 2020, 91, 13321. [CrossRef]

12. Wang, Y.; Wang, C.; Zhou, W.; Yang, F.; Chen, X.; Zhang, Q. Effects of wilting and Lactobacillus plantarum addition on the fermentation quality and microbial community of Moringa oleifera leaf silage. Front. Microbiol. 2018, 9, 1817. [CrossRef] [PubMed]

13. Ni, K.; Wang, F.; Zhu, B.; Yang, J.; Zhou, G.; Pan, Y.; Tao, Y.; Zhong, J. Effects of lactic acid bacteria and molasses additives on the microbial community and fermentation quality of soybean silage. Bioresour. Technol. 2017, 238, 706-715. [CrossRef]

14. Su, R.; Ni, K.; Wang, T.; Yang, X.; Zhang, J.; Liu, Y.; Shi, W.; Yan, L.; Jie, C.; Zhong, J. Effects of ferulic acid esterase-producing Lactobacillus fermentum and cellulase additives on the fermentation quality and microbial community of alfalfa silage. PeerJ 2019, 7, 7712. [CrossRef] [PubMed]

15. Ren, H.; Feng, Y.; Pei, J.; Li, J.; Wang, Z.; Fu, S.; Zheng, Y.; Li, Z.; Peng, Z. Effects of Lactobacillus plantarum additive and temperature on the ensiling quality and microbial community dynamics of cauliflower leaf silages. Bioresour. Technol. 2020, 307, 123238. [CrossRef] [PubMed]

16. Broderick, G.A.; Kang, J.H. Automated simultaneous determination of ammonia and total amino acids in ruminal fluid and In vitro media. J. Dairy Sci. 1980, 63, 64-75. [CrossRef]

17. Playne, M.; McDonald, P. The buffering constituents of herbage and of silage. J. Sci. Food Agric. 1966, 17, 264-268. [CrossRef]

18. Wang, T.; Teng, K.; Cao, Y.; Shi, W.; Xuan, Z.; Zhou, J.; Zhang, J.; Zhong, J. Effects of Lactobacillus hilgardii 60TS-2, with or without homofermentative Lactobacillus plantarum B90, on the aerobic stability, fermentation quality and microbial community dynamics in sugarcane top silage. Bioresour. Technol. 2020, 312, 123600. [CrossRef] [PubMed]

19. Murphy, R.P. A method for the extraction of plant samples and the determination of total soluble carbohydrates. J. Sci. Food Agric. 1958, 9, 714-717. [CrossRef]

20. Association of Official Analytical Chemists. Official Methods of Analysis; Association of Official Analytical Chemists: Arlington, VA, USA, 1990.

21. VanSoest, P.H.; Robertson, J.B.; Lewis, B.A. Methods for dietary fiber, neutral detergent fiber, and nonstarch polysaccharides in relation to animal nutrition. J. Dairy Sci. 1991, 74, 3583-3597. [CrossRef]

22. Ni, K.; Zhao, J.; Zhu, B.; Su, R.; Pan, Y.; Ma, J.; Zhou, G.; Tao, Y.; Liu, X.; Zhong, J. Assessing the fermentation quality and microbial community of the mixed silage of forage soybean with crop corn or sorghum. Bioresour. Technol. 2018, 265, 563-567. [CrossRef]

23. Wang, X.; Sun, G.; Feng, T.; Zhang, J.; Huang, X.; Wang, T.; Xie, Z.; Chu, X.; Yang, J.; Wang, H. Sodium oligomannate therapeutically remodels gut microbiota and suppresses gut bacterial amino acids-shaped neuroinflammation to inhibit Alzheimer's disease progression. Cell Res. 2019, 29, 787-803. [CrossRef]

24. Xie, Z.; Zhang, T.; Chen, X.; Li, G.; Zhang, J. Effects of maturity stages on the nutritive composition and silage quality of whole crop wheat. Asian-Australas. J. Anim. Sci. 2012, 25, 1374-1380. [CrossRef] [PubMed]

25. Weissbach, F.; Honig, H. On the anticipation and control of the run of fermentation silage making from extensively grown forages. Landbauforchung Völkenrode 1996, 46, 10-17, (In German, English Summary).

26. Guo, X.; Ke, W.; Ding, W.; Ding, L.; Xu, D.; Wang, W.; Zhang, P.; Yang, F. Profiling of metabolome and bacterial community dynamics in ensiled Medicago sativa inoculated without or with Lactobacillus plantarum or Lactobacillus buchneri. Sci. Rep. 2018, 8, 357. [CrossRef] [PubMed]

27. Broderick, G.A.; Walgenbach, R.P.; Sterrenburg, E. Performance of lactating dairy cows fed alfalfa or red clover silage as the sole forage. J. Dairy Sci. 2000, 83, 1543-1551. [CrossRef]

28. Cai, Y.; Benno, Y.; Ogawa, M.; Ohmomo, S.; Kumai, S.; Nakase, T. Influence of Lactobacillus spp. from an inoculant and of Weissella and Leuconostoc spp. from forage crops on silage fermentation. Appl. Environ. Microbiol. 1998, 64, 2982-2987. [CrossRef]

29. Oliveira, A.S.; Weinberg, Z.G.; Ogunade, I.M.; Cervantes, A.A.P.; Arriola, K.G.; Jiang, Y.; Kim, D.; Li, X.; Gonçalves, M.C.M.; Vyas, D.; et al. Meta-analysis of effects of inoculation with homofermentative and facultative heterofermentative lactic acid bacteria on silage fermentation, aerobic stability, and the performance of dairy cows. J. Dairy Sci. 2017, 100, 4587-4603. [CrossRef]

30. Ávila, C.L.S.; Carvalho, B.F. Silage fermentation-updates focusing on the performance of microorganisms. J. Appl. Microbiol. 2020, 128, 966-984. [CrossRef]

31. Kung, L., Jr.; Ranjit, N.K. The effect of Lactobacillus buchneri and other additives on the fermentation and aerobic stability of barley silage. J. Dairy Sci. 2001, 84, 1149-1155. [CrossRef]

32. Zhang, Q.; Wu, B.; Nishino, N.; Wang, X.; Yu, Z. Fermentation and microbial population dynamics during the ensiling of native grass and subsequent exposure to air. Anim. Sci. J. 2016, 87, 389-397. [CrossRef] 
33. Li, X.; Chen, F.; Wang, X.; Sun, L.; Guo, L.; Xiong, Y.; Wang, Y.; Zhou, H.; Jia, S.; Yang, F. Impacts of low temperature and ensiling period on the bacterial bommunity of oat silage by SMRT. Microorganisms 2021, 9, 274. [CrossRef] [PubMed]

34. Yan, Y.; Li, X.; Guan, H.; Huang, L.; Ma, X.; Peng, Y.; Li, Z.; Nie, G.; Zhou, J.; Yang, W.; et al. Microbial community and fermentation characteristic of Italian ryegrass silage prepared with corn stover and lactic acid bacteria. Bioresour. Technol. 2019, 279, 166-173. [CrossRef] [PubMed]

35. Herrmann, C.; FitzGerald, J.; O'Shea, R.; Xia, A.; O'Kiely, P.; Murphy, J.D. Ensiling of seaweed for a seaweed biofuel industry. Bioresour. Technol. 2015, 196, 301-313. [CrossRef]

36. Borreani, G.; Tabacco, E.; Schmidt, R.J.; Holmes, B.J.; Muck, R.E. Silage review: Factors affecting dry matter and quality losses in silages. J. Dairy Sci. 2018, 101, 3952-3979. [CrossRef] [PubMed]

37. Ertekin, İ.; Kızılşimşek, M. Effects of lactic acid bacteria inoculation in pre-harvesting period on fermentation and feed quality properties of alfalfa silage. Asian-Australas. J. Anim. Sci. 2019, 33, 245-253. [CrossRef]

38. Hackmann, T.J.; Sampson, J.D.; Spain, J.N. Comparing relative feed value with degradation parameters of grass and legume forages. J. Anim. Sci. 2008, 86, 2344-2356. [CrossRef]

39. Xu, D.; Ding, Z.; Wang, M.; Bai, J.; Ke, W.; Zhang, Y.; Guo, X. Characterization of the microbial community, metabolome and biotransformation of phenolic compounds of sainfoin (Onobrychis viciifolia) silage ensiled with or without inoculation of Lactobacillus plantarum. Bioresour. Technol. 2020, 316, 123910. [CrossRef]

40. Xu, D.; Ding, W.; Ke, W.; Li, F.; Zhang, P.; Guo, X. Modulation of metabolome and bacterial community in whole crop Corn silage by inoculating homofermentative Lactobacillus plantarum and heterofermentative Lactobacillus buchneri. Front. Microbiol. 2018, 9, 3299. [CrossRef]

41. Heinl, S.; Wibberg, D.; Eikmeyer, F.; Szczepanowski, R.; Blom, J.; Linke, B.; Goesmann, A.; Grabherr, R.; Schwab, H.; Pühler, A.; et al. Insights into the completely annotated genome of Lactobacillus buchneri CD034, a strain isolated from stable grass silage. J. Biotechnol. 2012, 161, 153-166. [CrossRef]

42. Pei, K.; Ou, J.; Huang, J.; Ou, S. p-Coumaric acid and its conjugates: Dietary sources, pharmacokinetic properties and biological activities. J. Sci. Food Agric. 2016, 96, 2952-2962. [CrossRef]

43. Li, W.; Yuan, S.; Sun, J.; Li, Q.; Jiang, W.; Cao, J. Ethyl $p$-Coumarate exerts antifungal activity in vitro and in vivo against fruit Alternaria alternata via membrane-targeted mechanism. Int. J. Food Microbiol. 2018, 278, 26-35. [CrossRef]

44. Brown, G.K.; Cromby, C.H.; Manning, N.J.; Pollitt, R.J. Urinary organic acids in succinic semialdehyde dehydrogenase deficiency: Evidence of alpha-oxidation of 4-hydroxybutyric acid, interaction of succinic semialdehyde with pyruvate dehydrogenase and possible secondary inhibition of mitochondrial beta-oxidation. J. Inherit. Metab. Dis. 1987, 10, 367-375. [CrossRef] [PubMed]

45. Zhang, W.; Jiang, H.; Yang, J.; Jin, M.; Du, Y.; Sun, Q.; Cao, L.; Xu, H. Safety assessment and antioxidant evaluation of betulin by LC-MS combined with free radical assays. Anal. Biochem. 2019, 587, 113460. [CrossRef]

46. Zhang, H.; Liu, Y.Z.; Xu, W.C.; Chen, W.J.; Wu, S.; Huang, Y.Y. Metabolite and microbiome profilings of Pickled Tea elucidate the role of anaerobic fermentation in promoting high levels of gallic acid accumulation. J. Agric. Food Chem. 2020, 68, 13751-13759. [CrossRef] [PubMed]

47. Mishra, S.; Zhang, W.; Lin, Z.; Pang, S.; Huang, Y.; Bhatt, P.; Chen, S. Carbofuran toxicity and its microbial degradation in contaminated environments. Chemosphere 2020, 259, 127419. [CrossRef] [PubMed] 